\title{
Parâmetros da degradação protéica ruminal de diferentes alimentos e rações estimados por técnica in vitro
}

[Parameters of ruminal protein degradation of different feeds and diets estimated by an in vitro method]

\author{
R.P. Lana ${ }^{1,4}$, W.M. Leopoldino ${ }^{2,4}$, J.S. Oliveira ${ }^{3,5}$, R.G. Veloso ${ }^{3,4}$ \\ P.M.M. Nunes ${ }^{3,4}$, A.C. Queiroz ${ }^{1,4}$ \\ ${ }^{1}$ Departamento de Zootecnia - UFV \\ Av. P.H. Rolfs, $\mathrm{s} / \mathrm{n}$ \\ 36.571-000 - Viçosa, MG \\ ${ }^{2}$ Aluno de pós-graduação - UFV - Viçosa, MG \\ ${ }^{3}$ Aluno de graduação - UFV - Viçosa, MG \\ ${ }^{4}$ Bolsista do CNPq \\ ${ }^{5}$ Bolsista da FAPEMIG
}

\begin{abstract}
RESUMO
Foram realizados três experimentos para estudar os parâmetros de degradação protéica ruminal. No primeiro, foram incubadas, em líquido ruminal de bovinos, dietas isoprotéicas contendo capim-elefante, fubá de milho e farelo de soja, em cinco níveis de concentrado (0:100, 25:75, 50:50, 75:25 e 100:0), adicionado ou não de monensina $(5 \mu \mathrm{M})$. Houve efeito linear decrescente do nível de concentrado sobre a concentração de amônia e degradabilidade da proteína bruta (DPB), e efeito cúbico sobre a concentração de proteína solúvel, com máximo valor em dieta com $25 \%$ de concentrado. A monensina diminuiu a DPB e a concentração de proteína solúvel, sem afetar a produção de amônia. No segundo experimento, foram incubados cinco diferentes volumosos (silagens de milho - Zea mays L. e de capim-elefante - Pennisetum purpureum, silagem pré-secada de braquiária -Brachiaria decumbens, feno de Tifton 85 -Cynodon sp. amonizado e feno de Tifton 85). A silagem pré-secada de capim-braquiária e o feno de Tifton 85 amonizado apresentaram as maiores concentrações de amônia $(8,7$ e 5,3mg/dl) e proteína solúvel $(5,4$ e $7,0 \mathrm{mg} / \mathrm{dl}$ ), devido aos seus maiores teores de PB, seguidos da silagem de capim-elefante e feno de Tifton 85. A DPB variou de 29,6 a $80,6 \%$, para a silagem pré-secada de braquiária e para o feno de Tifton 85 , e a degradabilidade potencial da matéria seca de 40,1 a 64,3\%, para a silagem de capim-elefante e silagem pré-secada de braquiária, respectivamente. A degradabilidade efetiva da proteína bruta apresentou baixos valores devido à baixa taxa de degradação da fração insolúvel. No terceiro experimento, foram incubados diferentes tipos de camas de frango (casca de café, capim-elefante seco picado, sabugo de milho ou cepilho), contendo ou não monensina $(5 \mu \mathrm{M})$. Não houve diferença nas concentrações de amônia entre as diferentes camas de frango, na ausência de monensina. Entretanto, com monensina, a cama de capimelefante apresentou o menor nível de amônia e a de cepilho, o maior. As camas influenciaram o conteúdo de proteína solúvel e a DPB, que variaram de 9,0 a $14,5 \mathrm{mg} / \mathrm{dl}$ e 39 a $63 \%$, respectivamente, sem efeitos da monensina.
\end{abstract}

Palavras-chave: bovino, rúmen, produção de amônia, monensina, volumoso, concentrado, cama-de-frango

\begin{abstract}
Three experiments were carried out in order to study the parameters of ruminal protein degradation. In the first, isoproteic diets, constituted of elephant grass, ground corn and soybean meal, at five concentrate levels (0:100, 25:75, 50:50, 75:25 e 100:0), with or without monensin (5 $\mu M)$, were incubated in ruminal fluid of bovines. There was a decreasing linear effect of the concentrate level on ammonia concentration and degradability of crude protein, and cubic effect in soluble protein concentration, with
\end{abstract}


the largest value in the diet with $25 \%$ concentrate. Monensin decreased degradability of crude protein and soluble protein concentration with no effect on ammonia production. In the second, five different roughages (corn and elephant grass silage - Pennisetum purpureum, Brachiaria haylage - Brachiaria decumbens, ammoniated Tifton 85 hay - Cynodon sp. e Tifton 85 hay). The were incubated Brachiaria haylage and the ammoniated Tifton 85 hay showed the greatest concentrations of ammonia (8.7 and $5.3 \mathrm{mg} / \mathrm{dl})$ and soluble protein (5.4 and $7.0 \mathrm{mg} / \mathrm{dl})$, due to their higher crude protein content, followed by elephant grass silage and Tifton 85 hay. The degradability of crude protein ranged from 29.6 to $80.6 \%$ for Brachiaria haylage and Tifton 85 hay, and the degradability of dry matter ranged from 40.1 to $64.3 \%$ for elephant grass silage and Brachiaria haylage, respectively. The effective degradability of crude protein showed low values due to low degradation rate of the insoluble fraction. In the third, four different poultry litter (hulls coffee, shopped dry elephant grass, corn cobs and wood shavings) were incubated, with or without monensin $(5 \mu M)$. No difference in ammonia concentration among the poultry litter samples, was observed in the absence of monensin. However, when monensin was present, the grass poultry litter showed the lowest ammonia level and wood poultry litter the highest. The poultry litter influenced the soluble protein content and the degradability of crude protein, which ranged from 9.0 to $14.5 \mathrm{mg} / \mathrm{dl}$ and 39 to $63 \%$, respectively, with no monensin effects.

Keywords: cattle, rumen, ammonia production, monensin, roughage, concentrate, poultry litter

\section{INTRODUÇÃO}

A degradabilidade da proteína dos alimentos pode ser estimada por técnica in vitro, por meio do qual as bactérias ruminais são cultivadas com a adição de fontes protéicas, associadas a diferentes níveis e fontes energéticas, para determinar as produções de amônia e gases. A degradabilidade das fontes protéicas é obtida dividindo-se a produção de amônia na ausência de produção de gases pelo total de nitrogênio do substrato. O nível "zero" de produção de gases corresponde à inexistência de incorporação da amônia proveniente da degradação da proteína do alimento na proteína microbiana, o que subestimaria a degradabilidade da fonte protéica (Raab et al., 1983).

Outras técnicas têm utilizado o tolueno para inibir a deaminação e a hidrazina para inibir a produção e utilização de amônia pelos microrganismos ruminais, evitando, assim, erros na determinação da degradabilidade da proteína (Broderick, 1995). O uso de proteases de plantas (ficina) e enzimas obtidas de fungos e bactérias, em vez da população microbiana, em meio anaeróbio, foi avaliado por Bartle et al. (1986), sendo a enzima mais utilizada proveniente da bactéria Streptomyces griseus. A degradação da proteína pelos métodos do tolueno, hidrazina e proteases é determinada medindo os aminoácidos em suspensão no meio.

No entanto, pode-se estimar a degradabilidade da proteína dos alimentos, levando-se em consideração a proporção do nitrogênio solubilizado no meio de cultura na forma de amônia, proteína, peptídeos solúveis e proteína microbiana ao longo da incubação, em relação à quantidade total de nitrogênio do alimento incubado. Este método tem como vantagem, em relação aos métodos descritos anteriormente, permitir avaliar o efeito de alguns fatores que afetam o metabolismo ruminal do nitrogênio, tais como a acidez do meio e a presença de ionóforos, tanino e lipídios. Ainda, sua rapidez e baixo custo, quando comparados aos métodos in vivo e in situ, eliminam a necessidade de se utilizar grande número de animais.

Os métodos da degradação da proteína in vitro têm mostrado valores próximos aos obtidos pelos métodos in vivo e in situ, podendo substituí-los (Luchini et al., 1996; Gizzi et al., 1998). Segundo Latham et al. (1971), os sistemas usados para incubações com conteúdo ruminal in vitro aproximam-se das condições in vivo, principalmente quanto às mudanças na concentração dos produtos finais da fermentação e no número de bactérias totais.

O objetivo deste trabalho foi estudar uma técnica de estimação da degradabilidade da proteína bruta de diferentes fontes de alimentos e dietas, mediante a incubação em meio de cultura contendo líquido ruminal, e monitorar a produção de amônia e proteína em suspensão no meio. 


\section{MATERIAL E MÉTODOS}

Em um primeiro experimento, avaliaram-se dietas constituídas de capim-elefante (CE), fubá de milho (FM) e farelo de soja (FS), em cinco diferentes proporções de volumoso e concentrado (Tab. 1), por meio de incubações in vitro com líquido ruminal.

Tabela 1. Teor de proteína bruta (PB) e composição das diferentes dietas incubadas no experimento 1

\begin{tabular}{lccccc}
\hline \multirow{2}{*}{ Ingredientes (\%) } & \multicolumn{5}{c}{ Relação volumoso:concentrado } \\
\cline { 2 - 5 } & $100: 0$ & $75: 25$ & $50: 50$ & $25: 75$ & $0: 100$ \\
\hline CE & 100 & 75,0 & 50,0 & 25,0 & - \\
FM & - & 20,5 & 33,3 & 48,2 & 66,2 \\
FS & - & 11,5 & 16,7 & 26,8 & 33,8 \\
PB & 22,4 & 20,7 & 21,9 & 22,3 & 21,5 \\
\hline
\end{tabular}

$\mathrm{CE}=$ capim-elefante; $\mathrm{FM}$ = fubá de milho; $\mathrm{FS}$ = farelo de soja.

O líquido ruminal, proveniente de dois bovinos fistulados no rúmen e alimentados com capimelefante (Pennisetum purpureum), foi coletado duas horas após a alimentação. O líquido foi filtrado em quatro camadas de gaze, transportado em garrafa térmica para o laboratório, onde foi transferido para um Erlenmeyer, saturado com dióxido de carbono e colocado em banho-maria a $39^{\circ} \mathrm{C}$ por 30 minutos. O inóculo contendo populações de bactérias ruminais foi retirado da fase intermediária do Erlenmeyer após a flutuação das partículas sólidas pelo acúmulo de gases e a sedimentação dos protozoários e partículas de alimentos no fundo.

Foram incubados $300 \mathrm{mg}$ de matéria seca de cada dieta com $4 \mathrm{ml}$ de líquido ruminal e $15,6 \mathrm{ml}$ de tampão McDougall (Silva e Queiroz, 2002) em frascos de vidro $(50 \mathrm{ml})$ saturados com dióxido de carbono a $39^{\circ} \mathrm{C}$, durante 120 horas, conforme Pell et al. (1994), com e sem monensina, totalizando 10 tratamentos com três repetições. Foi adicionado $0,4 \mathrm{ml}$ de etanol contendo ou não o ionóforo monensina diluído, de modo que a concentração final do mesmo no meio de cultura atingisse o valor de $5 \mu \mathrm{M}$, conforme observado in vivo ao se utilizar a dosagem recomendada do produto comercial. Ainda, incubou-se líquido ruminal e meio de cultura, sem a presença das dietas, que foi utilizado como branco, para calcular a degradabilidade da proteína dos alimentos.

Para a estimação da degradabilidade da proteína bruta, realizaram-se coletas de $0,5 \mathrm{ml}$ do meio de cultura nos tempos zero, 24, 48, 72, 96 e 120 horas, acondicionados em microtubos (eppendorf) para posteriores análises da concentração de amônia (Chaney e Marbach, 1962) e proteína solúvel (Lowry et al., 1951), que incluem as de origem microbiana, proteína solúvel dos alimentos, peptídeos e aminoácidos.

No segundo experimento, foram avaliadas silagens de milho e de capim-elefante (Pennisetum purpureum), silagem pré-secada de braquiária (Brachiaria decumbens), feno de Tifton 85 (Cynodon sp) amonizado e feno de Tifton 85 , por meio de incubações in vitro.

Incubaram-se $300 \mathrm{mg}$ de matéria seca de cada volumoso com $4 \mathrm{ml}$ de líquido ruminal e $20 \mathrm{ml}$ de tampão McDougall (Silva e Queiroz, 2002) em frascos de vidro $(50 \mathrm{ml})$ saturados com dióxido de carbono a $39^{\circ} \mathrm{C}$, durante 144 horas, conforme Pell et al. (1994), totalizando cinco tratamentos com três repetições para estimativa da degradabilidade da proteína bruta e duas para a estimativa do desaparecimento da matéria seca. Neste último caso, as fermentações foram interrompidas nos tempos zero, 24, 48, 72, 96, 120 e 144 horas para se determinar a quantidade de resíduo pela filtração em cadinho com porosidade média, lavados em água e secos em estufa a $105^{\circ} \mathrm{C}$. Para a estimação da degradabilidade da proteína bruta, realizaram-se coletas de $0,5 \mathrm{ml}$ do meio de cultura nos tempos zero, 24, 48, 72, 96 e 120 horas, como descrito no primeiro experimento.

No terceiro experimento, os alimentos avaliados, também por meio de incubações in vitro, foram diferentes camas de frango constituídas de casca de café, capim-elefante seco picado, sabugo de milho ou cepilho, com teor de proteína bruta na matéria seca de $21,7,13,9,19,9$ e $21,3 \%$, respectivamente.

Foram incubados $200 \mathrm{mg}$ de matéria seca de cada cama com $4 \mathrm{ml}$ de líquido ruminal e $15,6 \mathrm{ml}$ de 
tampão McDougall (Silva e Queiroz, 2002) em frascos de vidro $(50 \mathrm{ml})$ saturados com dióxido de carbono a $39^{\circ} \mathrm{C}$, durante 120 horas, conforme Pell et al. (1994), com e sem monensina, totalizando oito tratamentos com três repetições. Foi adicionado $0,4 \mathrm{ml}$ de etanol (controle) contendo ou não o ionóforo monensina diluído (monensina), de modo que a concentração final do mesmo no meio de cultura atingisse o valor de $5 \mu \mathrm{M}$. O líquido ruminal foi obtido dos mesmos animais utilizados no primeiro experimento, mantidos nas mesmas condições e pelos mesmos procedimentos descritos. Também incubou-se o branco, como nos experimentos anteriores.

Para a estimação da degradabilidade da proteína bruta, realizaram-se coletas de $0,5 \mathrm{ml}$ do meio de cultura nos tempos zero, 24, 48, 72, 96 e 120 horas, conforme descrito para o primeiro experimento.

A degradabilidade da proteína bruta (DPB) foi determinada a partir do nitrogênio utilizado na produção de amônia, proteína solúvel e crescimento microbiano em 120 ou 144 horas de incubação, dividido pela quantidade de nitrogênio do alimento, conforme a equação proposta por Lana et al. (2000).

As quantidades de nitrogênio presentes na amônia, proteína solúvel, proteína microbiana e alimentos foram calculadas com o uso das seguintes fórmulas, elaboradas no presente trabalho:

$$
\mathrm{DPB}=\frac{(\mathrm{NNH} 3+\mathrm{NPMS})}{\mathrm{NA}} \mathrm{X100}, \quad \text { (equação 1) }
$$

em que: DPB é a degradabilidade da proteína; NNH3 é o nitrogênio utilizado na produção de amônia (mg/dl); NPMS é o nitrogênio presente na forma de proteína microbiana e proteína solúvel, peptídeos e aminoácidos em suspensão $(\mathrm{mg} / \mathrm{dl})$; NA é nitrogênio presente no alimento incubado (mg).

mg N-NH ${ }_{3}=\left(\Delta \mathrm{NH}_{3}(96-0 h) \times 14\right) / 100$

mg N-proteína solúvel $=(\Delta$ proteína solúvel $(96-$ $0 \mathrm{~h})) /(6,25 * 100)$

$\mathrm{mg}$ N-proteína microbiana $=(\Delta$ proteína microbiana $(96-0 \mathrm{~h})) /(6,25 * 100)$

$\mathrm{mg} \mathrm{N}$-alimento $=($ alimento $(\mathrm{mg}) \times$ proteína bruta $(\% / 100)) / 6,25$

em que:
$\Delta \mathrm{NH}_{3}$ (96-0h) = concentração final concentração inicial de amônia, em $\mathrm{mmol} / 1000 \mathrm{ml}$ ou $\mathrm{mM}$

$14=$ peso atômico do nitrogênio

$100=1000 / 10 \mathrm{ml}$ de líquido de rúmen

$\Delta$ Proteína solúvel $(96-0 \mathrm{~h})=$ concentração final concentração inicial de proteína solúvel, em mg/l 6,25 = relação proteína: $\mathrm{N}$

$\Delta$ Proteína microbiana $(96-0 \mathrm{~h})=$ concentração final - concentração inicial de proteína microbiana, em mg/l

No segundo e terceiro experimentos, além da degradabilidade, foi também determinada a degradabilidade efetiva (DE) da proteína, calculada considerando-se a taxa de passagem ruminal igual a $0,05 \mathrm{~h}^{-1}$, segundo Ørskov e Mcdonald (1979):

$\mathrm{DE}=\mathrm{a}+\frac{(\mathrm{bxc})}{\mathrm{c}+\mathrm{k}}, \quad$ (equação 2)

em que: a, b e c são provenientes da equação de degradabilidade da proteína, determinada por meio do modelo proposto por Mehrez e Ørskov (1977), sendo:

$$
\left.\mathrm{p}=\mathrm{a}+\mathrm{b}\left(1-\mathrm{e}^{-\mathrm{ct}}\right), \quad \text { (equação } 3\right)
$$

em que: $\mathrm{p}$ é a degradabilidade no tempo t; a é a fração solúvel; b é a fração potencialmente degradável; c é a taxa de degradação de b; t é o tempo de incubação.

A determinação dos parâmetros de degradação e a degradabilidade efetiva não foram possíveis no primeiro experimento, pois os resultados da degradabilidade não se ajustaram ao modelo de Mehrez e Ørskov (1977).

$\mathrm{Na}$ análise da degradabilidade da proteína bruta, da produção de amônia e da proteína solúvel, foi utilizado o delineamento inteiramente ao acaso, em fatorial $5 \times 2$ (cinco dietas, com e sem monensina) para o primeiro experimento, cinco tratamentos (fontes de volumoso) para o segundo e fatorial 4 × 2 (quatro camas, com e sem monensina) para o terceiro, todos com três repetições (tubos de cultura).

As análises estatísticas foram realizadas utilizando o procedimento ANOVA do pacote estatístico SAS (User's..., 1996), incluindo os efeitos principais e de interação. Quando houve efeito de dieta, as médias foram comparadas por regressão ou pelo teste Tukey adotando-se $\alpha=0,05$. Para os parâmetros de degradação da 
proteína e porcentagem de matéria seca, foram relatadas somente as médias.

\section{RESULTADOS E DISCUSSÃO}

$\mathrm{Na}$ Fig.1a mostram-se as proporções de nitrogênio nos alimentos do segundo experimento e no meio de cultura, antes (A) e ao longo das incubações. Assim como nos resultados dos outros dois experimentos, apenas 8 a $22 \%$ do total de nitrogênio incubado foram provenientes do meio de cultura, esperando-se, portanto, pequena interferência por contaminação nas análises realizadas.

Na Fig. 1b apresentam-se as proporções médias de nitrogênio dos alimentos volumosos do experimento dois, ao longo da incubação, na forma de nitrogênio não degradado (NA) e

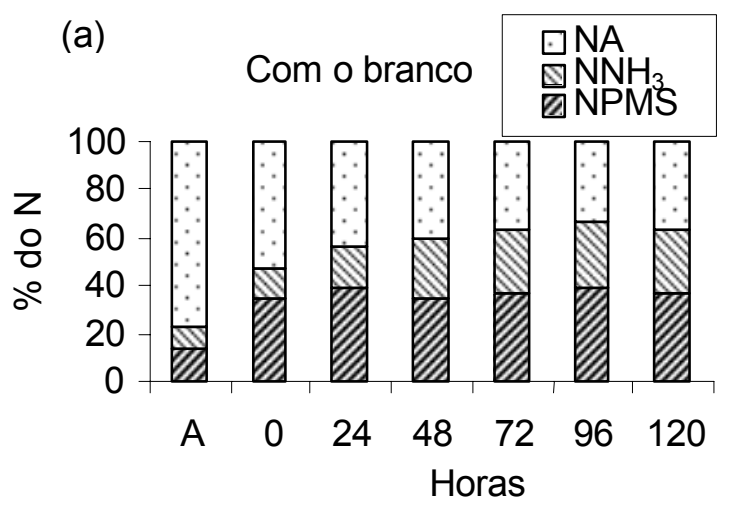

nitrogênio degradado em amônia $\left(\mathrm{NNH}_{3}\right)$ e proteína microbiana + proteína solúvel (NPMS), no qual foi descontado, em todos os tempos de incubação, o nitrogênio presente originalmente no meio de cultura. De maneira geral, houve aumento da proteína solúvel e do nitrogênio amoniacal, porém esse último foi mais acentuado, especialmente no primeiro experimento, no qual se incubaram níveis crescentes de concentrado nas dietas.

No início da incubação, a maior parte do nitrogênio degradado estava presente na forma de proteína solúvel (Fig. 1b). Com o avançar da fermentação, a proporção de nitrogênio nessa fração não se alterou, mas houve aumento substancial do nitrogênio amoniacal, ou seja, a proteína insolúvel, mas potencialmente degradável dos alimentos, foi convertida em amônia.

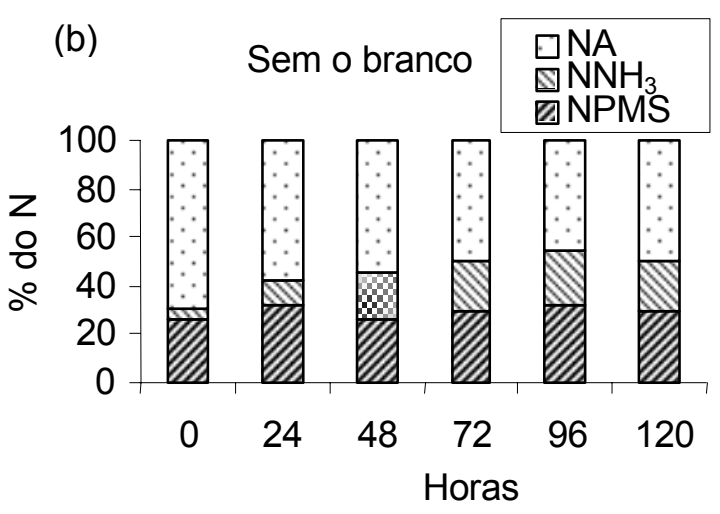

Figura 1. Porcentagem média do nitrogênio contido no alimento (NA) e nas formas de amônia $\left(\mathrm{NNH}_{3}\right)$ e proteínas microbiana+solúvel (NPMS) antes (A) e ao longo da incubação de diferentes volumosos (Experimento 2). As ilustrações apresentam os acúmulos de $\mathrm{NNH}_{3}$ e NPMS, sem descontar (a) ou descontando (b) os mesmos presentes inicialmente no líquido ruminal.

Houve redução linear na concentração de amônia em 120 horas de incubação e na degradabilidade da proteína bruta (determinada pela equação 1; $\mathrm{P}<0,05)$ pela substituição do volumoso pelo concentrado na dieta, e efeito cúbico na concentração de proteína solúvel, em que o maior valor foi observado na dieta com $25 \%$ de concentrado (Tab. 2). A monensina diminuiu a degradabilidade da proteína bruta e a concentração de proteína solúvel $(\mathrm{P}<0,05)$, sem ocorrer efeito sobre a produção de amônia e interação com as dietas $(\mathrm{P}>0,05)$. A redução na produção de amônia e degradabilidade da proteína pelo aumento do nível de concentrado pode ter ocorrido pela queda de $\mathrm{pH}$, uma vez que o fubá de milho resulta em menor $\mathrm{pH}$ final do meio de cultura, ou pela menor degradabilidade da proteína do milho, que foi utilizado em $70 \%$ na dieta com $100 \%$ de concentrado. O abaixamento do $\mathrm{pH}$ prejudica a atividade desaminadora, diminuindo a formação de amônia (Cunha, 1999). Além disso, pelo fato de os ionóforos inibirem a população microbiana com alta capacidade de desaminação de aminoácidos (Russell et al., 1988; Chen e Russell, 1988), é justificável que ocorra acúmulo de peptídeos e de proteína solúvel no meio de cultura. Neste caso, há maior fluxo de aminoácidos para ser utilizado pelo animal ruminante no intestino delgado. 
Parâmetros da degradação protéica ruminal...

Tabela 2. Variações nas concentrações de amônia, proteína solúvel e degradabilidade da proteína bruta (DPB), de dietas contendo nível crescente de concentrado, com e sem monensina, em 120 horas de incubação (Experimento 1)

\begin{tabular}{llllllll}
\hline \multirow{2}{*}{ Parâmetros } & \multicolumn{4}{c}{ Dietas (\% de concentrado) } & \multicolumn{2}{c}{ Sem } & Com \\
\cline { 2 - 6 } & 0 & 25 & 50 & 75 & 100 & Monensina & Monensina \\
\hline N-NH $3(\mathrm{mg} / \mathrm{dl})$ & 20,3 & 19,9 & 17,9 & 16,8 & 16,2 & $18,9 \mathrm{a}$ & $17,5 \mathrm{a}$ \\
N-prot. Solúvel $(\mathrm{mg} / \mathrm{dl})^{2}$ & 6,15 & 8,20 & 6,85 & 5,80 & 5,55 & $7,25 \mathrm{a}$ & $5,75 \mathrm{~b}$ \\
DPB (\%) & 78,7 & 86,7 & 75,4 & 68,6 & 67,6 & $80,1 \mathrm{a}$ & $70,7 \mathrm{~b}$ \\
\hline
\end{tabular}

$\mathrm{N}_{-N H}(\mathrm{mg} / \mathrm{dl})=19,42-0,047 \mathrm{x}$, em que $\mathrm{x}$ representa $0,25,50,75$ e $100 \%$ de concentrado.

${ }^{2}$ Proteína solúvel $(\mathrm{mg} / \mathrm{dl})=3,41+0,247 \mathrm{x}-0,0052 \mathrm{x}^{2}+0,00003 \mathrm{x}^{3}$, em que $\mathrm{x}$ representa $0,25,50,75$ e $100 \%$ de concentrado.

${ }^{3} \mathrm{DPB}(\%)=83,4-0,16 \mathrm{x}$, em que $\mathrm{x}$ representa $0,25,50,75$ e $100 \%$ de concentrado. Obtida da equação 1 .

Médias na mesma linha, para efeito de monensina, seguidas pela mesma letra não diferem pelo teste Tukey a $5 \%$ de probabilidade.

A degradabilidade da proteína (equação 1) variou de 68 a $87 \%$, sendo o menor valor observado no mais alto nível de concentrado. Isso mostra a possibilidade de se usar a técnica in vitro juntamente com a equação1, utilizada neste experimento como alternativa na determinação da degradabilidade de alimentos no rúmen pelas populações de bactérias. O modelo proposto por Mehrez e Ørskov (1977), para o estudo da cinética de degradação dos compostos nitrogenados, não se adequou aos dados obtidos no primeiro experimento, ou seja, não houve convergência. Por isso, não foi possível mostrar na Tab. 2 a degradabilidade efetiva e os parâmetros de degradação da proteína das dietas avaliadas.

No experimento dois, o teor de proteína bruta dos volumosos na matéria seca variou de 5,2 a $28,6 \%$. Observou-se diferença $(\mathrm{P}<0,05)$ entre os volumosos para as variações nas concentrações de amônia e proteína solúvel no meio de incubação e para degradabilidade da proteína bruta (equação 1; Tab. 3). A silagem pré-secada de braquiária e o feno de Tifton 85 amonizado apresentaram as maiores concentrações de amônia e proteína solúvel, devido aos seus maiores teores de PB, seguidos da silagem de capim-elefante e do feno de Tifton 85 .

Tabela 3. Teor de proteína bruta (PB), variações nas concentrações de amônia e proteína solúvel, degradabilidade da proteína bruta (DPB) e matéria seca (DMS), degradabilidade efetiva da proteína bruta (DEPB) e parâmetros de degradação da proteína (PB) de diferentes volumosos, em 144 horas de incubação (Experimento 2)

\begin{tabular}{|c|c|c|c|c|c|}
\hline \multirow{2}{*}{ Parâmetros } & \multicolumn{5}{|c|}{ Volumoso $^{1}$} \\
\hline & SM & SCE & SPS & Tif85amon & Tif85 \\
\hline PB (\% da MS) & 7,2 & 12,2 & 28,6 & 18,2 & 5,2 \\
\hline $\mathrm{N}-\mathrm{NH}_{3}(\mathrm{mg} / \mathrm{dl})^{2}$ & $1,25 \mathrm{c}$ & $2,20 \mathrm{c}$ & $8,70 \mathrm{~b}$ & $5,35 \mathrm{bc}$ & $2,10 \mathrm{c}$ \\
\hline $\mathrm{N}$-proteína solúvel $(\mathrm{mg} / \mathrm{dl})^{2}$ & $1,05 \mathrm{~d}$ & $2,15 \mathrm{~cd}$ & $5,45 \mathrm{bc}$ & $7,00 \mathrm{c}$ & $4,95 \mathrm{bc}$ \\
\hline DPB $(\%)^{2,3}$ & $52,0 \mathrm{c}$ & $51,7 \mathrm{c}$ & $29,6 \mathrm{~d}$ & $52,2 \mathrm{c}$ & $80,6 b$ \\
\hline DMS $(\%)^{4}$ & 45,6 & 40,1 & 64,3 & 60,5 & 48,9 \\
\hline $\operatorname{DEPB}(\%)^{5}$ & 28,1 & 41,1 & 16,4 & 35,1 & 21,9 \\
\hline \multicolumn{6}{|c|}{ Parâmetros de degradação da $\mathrm{PB}^{6}$} \\
\hline A & 21,6 & 38,1 & 11,9 & 20,2 & 0,9 \\
\hline $\mathrm{B}$ & 52,8 & 25,5 & 24,2 & 34,5 & 90,7 \\
\hline $\mathrm{C}$ & 0,007 & 0,007 & 0,012 & 0,038 & 0,015 \\
\hline
\end{tabular}

${ }^{1} \mathrm{SM}=$ silagem de milho; $\mathrm{SCE}=$ silagem de capim-elefante; SPS = silagem pré-secada de braquiária; Tif85amon = Feno de Tifton 85 amonizado; Tif $85=$ Feno de Tifton 85.

${ }^{2}$ Médias na mesma linha, seguidas pela mesma letra, não diferem pelo teste Tukey a 5\% de probabilidade.

${ }^{3}$ Obtidas da equação 1 em 144 horas de incubação.

${ }^{4}$ Obtidas por desaparecimento de peso em 144 horas de incubação.

${ }^{5}$ Obtidas da equação 2.

${ }^{6}$ Obtidos da equação 3. 
A degradabilidade da proteína bruta (equação 1) variou de 29,6 a $80,6 \%$, para a silagem présecada e para o feno de Tifton 85, e a degradabilidade da matéria seca (determinada por desaparecimento de matéria seca após 144 horas) de 40,1 a 64,3\%, para a silagem de capimelefante e silagem pré-secada, respectivamente (Tab. 3). A degradabilidade efetiva da proteína bruta (equação 2) apresentou baixos valores devido à baixa taxa de degradação da fração insolúvel (equação 3), mas potencialmente degradável (Fig. 1b).

Segundo Broderick (1995), a determinação da taxa e extensão da degradação da proteína com microrganismos ruminais, sem uso de inibidores de crescimento, é complicada, pois os microrganismos utilizam $\mathrm{o}$ produto de degradação em seu crescimento, resultando em subestimativas da degradação. Se isso ocorreu nestes experimentos, provavelmente parte da proteína microbiana sintetizada estaria aderida às partículas alimentares residuais, sendo liberada lentamente com a morte dos microrganismos após ocorrer acúmulo dos produtos de fermentação no meio, explicando a baixa taxa de degradação da fração b (equação 3).

$\mathrm{Na}$ Tab. 4 são apresentados os efeitos de tratamentos sobre as variações na concentração de amônia e de proteína solúvel em 120 horas de incubação e os parâmetros de degradabilidade (equação 3) e degradabilidade efetiva (equação 2) da proteína bruta. $\mathrm{Na}$ ausência de monensina, não houve diferença nas concentrações de amônia entre as diferentes camas de frango utilizadas. No entanto, quando a monensina estava presente, a cama de capim-elefante apresentou o menor $(5,25 \mathrm{mg} / \mathrm{dl})$ nível de amônia e a de cepilho, o maior $(13,10)(\mathrm{P}<0,05)$. A baixa produção de amônia observada na cama de capim pode estar relacionada ao menor teor protéico da mesma. Além disso, sabe-se que a maior quantidade de proteína bruta estimula maior produção de amônia, a maior população microbiana aumenta o potencial de produção de amônia e os antibióticos inibem a população bacteriana com alta produção de amônia (Chen e Russell, 1988; Russell et al., 1988).

Tabela 4. Efeito de diferentes camas de frango e monensina sobre as variações na concentração de amônia e proteína solúvel em 120 horas de incubação, degradabilidade (DPB) e degradabilidade efetiva (DEPB) da proteína bruta e parâmetros de degradação da proteína bruta (PB) (Experimento 3)

\begin{tabular}{|c|c|c|c|c|c|}
\hline \multirow{2}{*}{ Parâmetros } & & \multicolumn{4}{|c|}{ Cama de frango } \\
\hline & & Casca de café & Capim & Sabugo & Cepilho \\
\hline \multirow[t]{2}{*}{$\mathrm{N}-\mathrm{NH}_{3}, \mathrm{mg} / \mathrm{dl}$} & M- & $11,80 \mathrm{ab}$ & $6,40 \mathrm{ab}$ & $7,60 \mathrm{ab}$ & $11,55 \mathrm{ab}$ \\
\hline & $\mathrm{M}+$ & $6,80 \mathrm{~b}$ & $5,25 \mathrm{~b}$ & $9,55 \mathrm{ab}$ & $13,10 \mathrm{a}$ \\
\hline \multicolumn{2}{|c|}{ N-prot. solúvel(mg/dl) ${ }^{1}$} & $14,55 \mathrm{a}$ & $14,15 \mathrm{a}$ & $9,40 \mathrm{~b}$ & $10,75 \mathrm{ab}$ \\
\hline \multicolumn{2}{|l|}{$\operatorname{DPB}(\%)^{1,2}$} & $49,2 \mathrm{ab}$ & $62,6 \mathrm{a}$ & $39,5 b$ & $47,3 \mathrm{~b}$ \\
\hline \multicolumn{2}{|l|}{$\operatorname{DEPB}(\%)^{3}$} & 28,1 & 34,1 & 29,6 & 36,6 \\
\hline \multicolumn{6}{|c|}{ Parâmetros de degradação da $\mathrm{PB}^{4}$} \\
\hline \multicolumn{2}{|c|}{ A } & 3,0 & 2,1 & 18,4 & 32,5 \\
\hline \multicolumn{2}{|l|}{$\mathrm{B}$} & 47,5 & 63,7 & 23,4 & 23,0 \\
\hline \multicolumn{2}{|l|}{$\mathrm{C}$} & 0,056 & 0,050 & 0,046 & 0,011 \\
\hline
\end{tabular}

$\mathrm{M}-=$ tratamento sem monensina; $\mathrm{M}+=$ tratamento com monensina

${ }^{1}$ Médias na mesma linha, seguidas pela mesma letra, não diferem pelo teste Tukey a $5 \%$ de probabilidade.

${ }^{2}$ Obtida da equação 1 .

${ }^{3}$ Obtida da equação 2 .

${ }^{4}$ Obtidos da equação 3

Neste experimento, a monensina não teve efeito na produção de amônia, provavelmente devido ao fato de os peptídeos e os aminoácidos serem os fatores limitantes neste processo, ou seja, os alimentos são pobres em proteína verdadeira (peptídeos e aminoácidos) e ricos em nitrogênio não-protéico, e não há atividade de desaminação. Trabalhos têm demonstrado que a monensina inibe de $33 \%$ a $36 \%$ a atividade microbiana de produção de amônia em meios de cultura 
contendo $5 \mu \mathrm{M}$ de monensina e excesso de peptídeos (15g/l) (Chen e Russell, 1991; Yang e Russell, 1993). Segundo Erfle et al. (1982) e Lana et al. (1998), a maior produção de amônia verificada para o farelo de soja está associada ao fato de este alimento ser rico em proteína e de maior degradabilidade em relação aos outros alimentos e, ainda, devido ao maior $\mathrm{pH}$ do meio, que aumenta a atividade de desaminação. Os níveis de peptídeos provenientes do alimento e remanescentes no meio de cultura são responsáveis por maiores ou menores produções de amônia (Cunha, 1999).

O tipo de cama influenciou $(\mathrm{P}<0,05)$ o conteúdo de proteína solúvel e a degradabilidade da proteína, que variou de 39 a 63\% (Tab. 3). Esses resultados mostram a degradação da proteína do alimento pela ação das populações de bactérias do rúmen, que varia de acordo com o teor de nitrogênio não-protéico e proteína (degradável ou não) presente no alimento. A degradação efetiva da proteína bruta (equação 2) variou de 28 a $37 \%$, devido às baixa taxas de degradação da fração b e aos baixos valores das frações a ou b (equação 3).

A monensina não afetou a degradabilidade da proteína das camas de frango, devido ao fato de os substratos utilizados serem de baixo valor protéico, ricos em nitrogênio não-protéico (50\%) e em proteína indigerível associado ao detergente ácido. Neste caso, espera-se menor atividade das bactérias gram-positivas, fermentadoras vigorosas de aminoácidos (Cunha, 1999). Isso mostra que as populações responsáveis pela degradação do alimento incubado não tinham sensibilidade à monensina, justificando, assim, a ausência de significância nos parâmetros estudados.

A proposta de se avaliar a degradação da proteína bruta dos alimentos pela equação 1 , proposta por Lana et al. (2000), é por esta $\left(\mathrm{DPB}=\frac{(\mathrm{NNH} 3+\mathrm{NPMS}) \times 100}{\mathrm{NA}}\right) \quad$ mostrar a degradação do nitrogênio do alimento pelas populações de bactérias ruminais, aproximando do que ocorre no rúmen do animal, apesar de não ter todas as condições ruminais. Ainda, poder estudar as influências de $\mathrm{pH}$, antibióticos, ionóforos, outras substâncias que venham agir sobre as populações de bactérias do rúmen interferindo na degradação dos alimentos. Portanto, a técnica in vitro associada a equação (1) possibilita avaliar a degradação da proteína pelas populações de bactérias do rúmen e, conseqüentemente, pelo animal, medindo o quanto da proteína bruta (nitrogênio*6,25) do alimento foi degradado pelos microrganismos incubados.

\section{CONCLUSÕES}

A monensina agiu reduzindo a concentração de proteína solúvel das dietas, e o concentrado diminuiu a produção de amônia. Conseqüentemente, ambos reduziram a degradabilidade da proteína pelo método in vitro com populações de bactérias do rúmen. $\mathrm{O}$ feno de Tifton 85 apresentou a maior degradabilidade, portanto melhor qualidade nutricional. A monensina não interferiu na degradabilidade da proteína das camas de frango. A técnica in vitro utilizada com a equação 1 mostrou-se capaz de determinar a degradação da proteína bruta dos alimentos avaliados pela ação das populações de bactérias incubadas do rúmen.

\section{REFERÊNCIAS BIBLIOGRÁFICAS}

BARTLE, S.J.; PRESTON, R.L.; GIBSON, M.L. In vitro evaluation of the $\mathrm{pH}$ effect on protein degradation and synthesis by rumen microorganisms. Nutr. Reprod. Int., v.34, p.1001-1009, 1986.

BRODERICK, G.A. Methodology for the determining ruminal degradability of feed proteins. In: SIMPÓSIO INTERNACIONAL SOBRE EXIGÊNCIAS NUTRICIONAIS DE RUMINANTES, 1995, Viçosa-MG. Anais... Viçosa: JARD, 1995. p.139-176.

CHANEY, A.L.; MARBACH, E.P. Modified reagents for determination of urea and ammonia. Clin. Chem., v.8, p.130-132, 1962.

CHEN, G.; RUSSELL, J.B. Fermentation of peptides and amino acids by a monensinsensitive ruminal peptostreptpcoccus. Appl. Environ. Microbiol., v.54, p.2742-2749, 1988.

CHEN, G.; RUSSELL, J.B. Effect of monensin and a protonophore on protein degradation, peptide accumulation, and deamination by mixed 
ruminal microorganisms in vitro. J. Anim. Sci., v.69, p.2196-2203, 1991.

CUNHA, L.T. Efeito da acidez e de ionóforos na degradação de proteínas por microrganismos ruminais. 1999. 43f. Dissertação (Mestrado em Microbiologia) - Universidade Federal de Viçosa, Viçosa, MG.

ERFLE, J.D.; BOILA,R.J.; TEATHER, R.M. et al. Effect of $\mathrm{pH}$ on fermentation characteristics and protein degradation by rumen microorganisms in vitro. J. Dairy Sci., v. 65, p. 1457-1464, 1982.

GIZZI, G.; ZANCHI, R.; SCIARAFFIA, F. Comparison of microbiological and fermentation parameters obtained with an improved rumen in vitro technique with those obtained in vivo. Anim. Feed Sci. Technol., v.73, p.291-305, 1998.

LANA, R.P.; RUSSELL, J.B.; AMBURGH, M.E.V. The role of $\mathrm{pH}$ in regulating ruminal methane and ammonia production. J. Anim. Sci., v.76, p.2190-2196, 1998.

LANA, R.P.; CUNHA, L.T.; BORGES, A.C. et al. Desenvolvimento de uma técnica para determinação da degradabilidade da proteína dos alimentos para ruminantes. Rev. Bras. Zoot., v.29, p.2119-2127, 2000.

LATHAM, M.J.; SHARPE, M.E.; SUTTON, J.D. The microbial flora of the rumen of cows fed hay and high cereal rations and its relationship to the rumen fermentation. J. Appl. Bacteriol., v.34, p.425-434, 1971.

LOWRY, O.H.; ROSEBROUGH, N.J.; FARR, A.L. et al. Protein measurement with the Folin phenol reagent. J. Biol. Chem., v.193, p.265-275, 1951.

LUCHINI, N.D.; BRODERICK, G.A.; COMBS, D.K. In vitro determination of ruminal protein degradation using freeze-stored ruminal microorganisms. J. Anim. Sci., v.74, p.24882499, 1996.
MEHREZ, A.Z.; ØRSKOV, E.R. A study of the artificial fibre bag technique for determining the digestibility of feeds in the rumen. J. Agric. Sci., v.88, p.645-665, 1977.

ØRSKOV, E.R.; MCDONALD, I. The estimation of protein degradability in the rumen from incubation mesurements weighted according to rate of passage. J. Agric. Sci., v.92, p.499-503, 1979.

PELL, A.N.; SCHOFIELD, P.; STONE, W.C. Rates of digestion of feeds measured "in vitro" with computers. In: CORNELL NUTRITION CONFERENCE FOR FEED MANUFACTURERS, 56., 1994, Rochester, NY. Proceedings... Ithaca: Cornell University, 1994. p. 74-81.

PEREIRA, J.C. Digestibilidade de camas de frangos em ovinos e caprinos. 1986. 49f. Dissertação (Mestrado em Zootecnia) Universidade Federal de Viçosa, MG.

RAAB, L.; CAFANTARIS, B.; JILG, T. et al. Rumen protein degradation and biosynthesis. Brit. J. Nutr., v.50, p.569-562, 1983.

RUSSELL, J.B.; STROBEL,H.J.; CHEN,G. The enrichment and isolation of a ruminal bacterium with a very high specific activity of ammonia production. Appl. Environ. Microbiol., v.54, p.872, 1988.

SILVA, D.J.; QUEIROZ, A.C. Análise de alimentos: métodos químicos e biológicos. 3. Viçosa: Editora UFV - 2002. 235p

USER'S guide. Statistical Release 6.12. Cary, NC: SAS Institute, 1996.

YANG, C.M.J.; RUSSELL, J.B. Effect of monensin on the specific activity of ammonia production by ruminal bacteria and disappearance of amino nitrogen from the rumen. Appl. Environ. Microbiol., v.59, p.3250-3254, 1993. 